\title{
AVALIAÇÃO DE RECURSOS GEOTERMAIS DA BACIA DO PARANÁ
}

\author{
Antonio Jorge de Lima Gomes \\ Orientador: Dr. Valiya Mannathal Hamza (ON) \\ 186 p. - Tese (Doutorado) - Defesa 25.09.2009
}

\begin{abstract}
RESUMO. Os resultados obtidos neste trabalho de Doutorado representam a primeira avaliação em escala regional de recursos geotermais da Bacia do Paraná. 0 trabalho se baseou na reavaliação de diversos estudos anteriores constantes na literatura e de aquisições complementares de dados nos Estados de São Paulo, Paraná, Santa Catarina, Goiás e Minas Gerais, o que permitiu avanços na qualidade e na quantidade das informações geotérmicas e melhorias na sua análise e interpretação. Os resultados indicam que os gradientes geotérmicos na área sedimentar estão compreendidos entre 16 e $46^{\circ} \mathrm{C} / \mathrm{km}$ com valor médio de $24 \pm 4^{\circ} \mathrm{C} / \mathrm{km}$. Os valores de fluxo térmico situam-se no intervalo de 40 a $100 \mathrm{~mW} / \mathrm{m}^{2}$ apresentando um valor médio de $67 \pm 6 \mathrm{~mW} / \mathrm{m}^{2}$. As distribuições regionais de gradiente e fluxo não apontam existência de anomalias térmicas de extensão regional na parte central da bacia. Esta constatação é interpretada como indicativo da atuação de processos termotectônicos em profundidades rasas na crosta, com consequente dissipação rápida de calor residual originários dos mesmos. Por outro lado, os resultados deste trabalho permitiram a identificação de três faixas anômalas de fluxo térmico relativamente elevado. A primeira situa-se na parte Norte - Noroeste da bacia com orientação Sudoeste Nordeste. É notável a proximidade desta faixa com o Lineamento Brasiliano e a extensão linear da feição estrutural Paraguai - Araguaia. A segunda atravessa a parte central da bacia, quase coincidente com a faixa de lineamentos magnéticos, seguindo a direção aproximada dos diques do Arco de Ponta Grossa. A sua orientação Sudeste - Noroeste é perpendicular à faixa A na parte Noroeste da bacia. A terceira se encontra localizada na borda Sudeste da bacia, apresentando orientação semelhante ao da primeira. A presença dessas faixas ortogonais de fluxo térmico relativamente elevado é considerada como indicativo da existência de um sistema de rifteamento subcrustal. 0 Recurso Base Geotermal da Bacia do Paraná é estimado na ordem de $8 \times 10^{23} \mathrm{~J}$. A parte recuperável de recursos se encontra associada a dois sistemas de aquíferos confinados: Guarani e de Furnas - Ponta Grossa. A primeira é de tipo baixa entalpia e se encontra em profundidades de 1 a $3 \mathrm{~km}$, enquanto a segunda é do tipo média entalpia e ocorre em profundidades de 3 a $5 \mathrm{~km}$ na parte central da bacia. As condições climáticas e de estrutura socioeconômica nas regiões Sul e Sudeste favorecem 0 aproveitamento em potencial desses recursos: 0 de tipo baixa entalpia para balneários e processos agro-industriais, e 0 do tipo média entalpia também para geração de energia elétrica com tecnologias futuras.
\end{abstract}

ABSTRACT. The results presented in this thesis project represent the first attempt for regional evaluation of geothermal resources of the Paraná Basin. The works carried out include reevaluation of the results of previous investigations as well as new complementary geothermal measurements in the states of São Paulo, Paraná, Santa Catarina, Goiás and Minas Gerais. The results indicate that the geothermal gradients in the sedimentary basin areas in the range of 16 to $46^{\circ} \mathrm{C} / \mathrm{km}$ with a mean value of $24 \pm 4^{\circ} \mathrm{C} / \mathrm{km}$. The heat flow values are in the range of 40 to $100 \mathrm{~mW} / \mathrm{m}^{2}$ with a mean of $67 \pm 6 \mathrm{~mW} / \mathrm{m}^{2}$. The regional distributions of geothermal gradients and heat flow did not reveal the presence of any significant positive thermal anomaly in the central parts of the basin. It implies that thermo-tectonic processes associated with basin formation operated at relatively shallow depths and consequently have left very little residual heat in the crustal layers. Nevertheless, it has been possible to identify three distinct orthogonal belts of relatively high heat flow. The first and most prominent one is situated in the north-western parts of the basin, almost coincident with the southwest - northeast trending Brasiliano Lineament and the Paraguay - Araguaia structural belt. The second one, that is relatively less prominent, cuts across the central parts of the basin, and is almost coincident with the southeast - northwest trending belt of dike swarms of the Ponta Grossa arch. The third one is located in the southwestern border of the basin, with orientation similar to that of the first one. The presence of these orthogonal belts has been interpreted as indicative of a deep seated crustal spreading center, similar in character to those of the current mid-ocean ridge systems. The geothermal resource base of the Paraná Basin has been estimated to be of the order of $8 \times 10^{23} \mathrm{~J}$. The recoverable parts of the resources are associated with two confined aquifer systems: Guarani and Furnas - Ponta Grossa. The first one of low enthalpy type is located at depths of 1 to $3 \mathrm{~km}$, while the second one of medium enthalpy type is located at depths of 3 to $5 \mathrm{~km}$ in the central parts of the basin. The low enthalpy resources are suitable for direct use applications in agro-industrial processes, while the medium enthalpy resources open up possibilities for electrical power generation in the southern and south-eastern parts of Brazil. 